\title{
In vitro anti-radical and anti-salmonella activities of sarcocephalus latifolius, lannea barteri, uvaria chamae, parkia biglobosa and khaya senegalensis
}

\begin{abstract}
This study aims to analyze the chemical compounds and evaluate the anti-radical and anti-Salmonella activities of extracts from Sarcocephalus latifolius, Lannea barteri, Uvaria chamae, Parkia biglobosa and Khaya senegalensis using respectively standards phytochemical methods, phosphomolybdates reduction method and micro dilution method in liquid medium associated with plating on agar medium. Qualitative phytochemical tests revealed the presence of alkaloids, flavonoids and tannins in all extracts. Quantitative phytochemical analysis showed that the stem bark of Khaya senegalensis, Parkia biglobosa and Lannea barteri displayed high anti-radical properties with respectively $9.12 \pm 0.17 \mathrm{mgEAA} / \mathrm{g}, 9.30 \pm 0.15 \mathrm{mgEAA} / \mathrm{g}$ and $8.28 \pm 0.23 \mathrm{mg} \mathrm{EAA} / \mathrm{g}$ values of antioxidants. Antimicrobial tests on Salmonella strains yielded MIC that varied with plants extracts: 6.25 to $12.5 \mathrm{mg} / \mathrm{ml}$ for Sarcocephalus latifolius and Lannea barteri, $25 \mathrm{mg} / \mathrm{ml}$ for Uvaria chamae, $50 \mathrm{mg} / \mathrm{ml}$ for Khaya Senegalensis and Parkia biglobosa. These observations could be use to design new drugs that will provide better therapeutic options for the treatment of Salmonellosis and oxidative-related diseases.
\end{abstract}

Keywords: plant extract, phytochemical analysis, anti-radical and anti-salmonella activities
Volume 7 Issue 2 - 2018

\author{
Gnatoulma Katawa,' Gatigbene Bomboma,' \\ Komi Komi-Koukoura,' Essoham Ataba,' \\ Adjoa HJG Ameyapoh,' Oukoe M \\ Amessoudji,' Kokou T Anani,' Simplice D \\ Karou, ${ }^{2}$ Yaovi Ameyapoh' \\ 'Ecole Supérieure des Techniques Biologiques et Alimentaires \\ (ESTBA), University of Lomé, Togo \\ ${ }^{2}$ Faculté Des Sciences (FDS), University of Lomé, Togo
}

Correspondence: Gnatoulma Katawa, Ecole Supérieure des Techniques Biologiques et Alimentaires, University of Lomé, BP I5 I 5, Lomé, Togo, Tel 002289304066 I,

Email mahkatawa@yahoo.fr

Received: March 03, 2018 | Published: March 19, 2018
Abbreviations: S. latifolius, sarcocephalus latifolius; $L$. barteri, lannea barteri; U. chamae: uvaria chamae; P. biglobosa, parkia biglobosa; K. senegalensis, khaya senegalensi; MIC, minimum inhibitory concentration; MBC, minimum bactericidal concentration; S. typhi, salmonella typhi; S. enteric, salmonella enteric; S. paratyphi, salmonella paratyphi; $S$. typhimirium, salmonella typhimirium; FCR, folin ciocalteu reagent; ND, not determined; EGA, equivalent gallic acid; EC, equivalent catechin; EAA, equivalent ascorbic acid; CERMETRA-TOGO, centre d'etude et de recherche en médecine traditionnelle apliquée du togo

\section{Introduction}

Infectious diseases account for $45 \%$ of deaths in low-income countries. Bacterial infections account for $70 \%$ of the mortality caused by microorganisms. ${ }^{1}$ The genus Salmonella, more specifically the serotype typhi or less frequently the serotypes paratyphi $\mathrm{A}, \mathrm{B}$ or $\mathrm{C}$ are responsible of typhoid fever and paratyphoid fever. Tens of millions of cases are recorded every year in the world, with over one hundred thousand deaths a year, the majority of them in developing countries. ${ }^{2}$ The increased resistance of microorganism's strains to the molecules presents on the market and the new WHO recommendations that require each country to introduce natural treatment methods into their health system are pushing many universities and pharmaceutical laboratories to explore medicinal plants, which are less expensive and have fewer side effects. ${ }^{3}$ It is in this perspective that the antiradical and the anti-Salmonella potential of the extracts from five medicinal plants used in the Togolese pharmacopoeia to treat fevers and gastroenteritis, has been done. These include Sarcocephalus latifolius, Lannea barteri, Uvaria chamae, Parkia biglobosa and Khaya senegalensis.

Sarcocephalus latifolius is a shrub of family Rubiaceae that usually grows in humid areas of tropical Africa. Its roots are used for several applications in traditional medicine. ${ }^{4}$ Its anti-radical properties have been reported by Antia et al..$^{5}$ Its roots extracts also have antibacterial activities against Salmonella and other bacteria. ${ }^{6}$ Lannea barteri is a tree of family Anacardiaceae whose preparation is used in the treatment of gastritis, fever among others. ${ }^{7}$ Njinga et al. ${ }^{8}$ showed the anti-Salmonella activity of its leaves extract. Uvaria chamae belong to the family Annonaceae. It is a plant from the Togolese Pharmacopoeia that is used in the treatment of gastrointestinal pain, yellowing, wound healing, fever and constipation. ${ }^{9}$ A phytochemical study conducted by Kone et al. ${ }^{10}$ showed that the aqueous extracts of the roots of the plant have anti-radical properties. Ogbulie et al. ${ }^{11}$ in 2007 reported its bactericidal effect against bacteria including Salmonella typhi. Parkia biglobosa is a tree of family Mimosaceae. It bears fruit in the form of long pods suspended in clusters, containing numerous black seeds coated with yellow pulp. Its trunk bark has been successfully used in the treatment of many diseases including fevers, diarrhea, and severe stomach aches. ${ }^{12}$ The anti-radical properties of trunk bark extract have been reported by Komelafe et al. ${ }^{13}$ The same extract is active against a large number of microorganisms including Salmonella typhi and Shigella dysenteriae. ${ }^{14}$ Khaya senegalensis is a tree of family Meliaceae that is used in the African pharmacopoeia to treat dermatitis, malaria, fever, jaundice and stomachaches. ${ }^{15}$ Atawodi et al. ${ }^{16}$ reported the anti-radical properties of the plant trunk bark 
extract. The anti-Salmonella action of the same extracts was shown in a previous study conducted by Abdallah et al. ${ }^{17}$

\section{Material and methods}

\section{Framework of study}

Extractions, phytochemical and microbiological tests were carried out in "Laboratoire de Microbiologie et de Contrôle de qualité des Denrées Alimentaires (LAMICODA)", of the University of Lomé.

\section{Plant material}

It is made up of different organs of medicinal plants harvested in the maritime region of Togo, in the localities of "Aképé", "Noépé" and "Badja" on 02-10- 2016. These are: the trunk bark of Khaya senegalensis, Parkia biglobossa and Lannea barteri, root bark of Sarcocephalus latifolius and roots of Uvaria chamae. The plants were authenticated in the Botanical Laboratory of the University of Lomé. The herbarium numbers are respectively TG01797, TG15084, TG09467, TG07536 and TG01950.

\section{Preparation of plants extracts}

The plant material is cut into small blocks and then dried out of the sun at the Laboratory temperature between 16 and 24 degrees Celsius before being pulverized. $500 \mathrm{ml}$ of the ethanol-water mixture $(70 \%$ $-30 \%$ ) is added to $100 \mathrm{~g}$ of vegetable powder previously weighed in a beaker. The whole is stirred for 24 hours and filtered on Wattman paper. The various filtrates obtained are evaporated at $40^{\circ} \mathrm{C}$ with a rotary evaporator. A solution of $100 \mathrm{mg} / \mathrm{ml}$ of the extracts was prepared by dissolving $5 \mathrm{~g}$ of dry extract in $50 \mathrm{ml}$ of distilled water. This extract solution was filtered through $0.45 \mu \mathrm{m}$ millipore membrane. The sterilized extract was used for antimicrobial test.

\section{Test organism}

Four strains of Salmonella were tested; two clinical strains (Salmonella typhi and Salmonella enterica) isolated in the Bacteriology Laboratory of "Institut National d'Hygiène (INH)" of Lomé in October 2017, and two reference strains (Salmonella typhimirium ATCC 14028 and Salmonella paratyphi ATCC 9150). These strains were isolated and then stored at $2-8^{\circ} \mathrm{C}$ on the nutrient agar. The two clinical strains tested are multirésistante. Salmonella enterica is resistant to more molecules than Salmonella typhi. Salmonella enterica is resistant to ampicillin, ticarcilin, cefalotin, cefoxitin, amikacin, gentamicin, tobramicin and nalidixic acid. Salmonella typhi is resistant to cefalotin, cefoxitin, amikacin, gentamicin and tobramicin.

\section{Bacteriological tests}

The authentication and antibiogram of the clinical strains were carried out on the VITEK 2 bioMérieux device, with the identification and antibiogram cards of the bioMérieux brand. The technique used for antibacterial tests is the microdilution in liquid medium combined with plating on agar medium. ${ }^{18,19}$ The strains of Salmonella are transplanted into the nutrient agar and incubated at $37^{\circ} \mathrm{C}$ for 24 hours (overnight). The following day, a control Gram was performed on the 24hours colonies and a microbial suspension was prepared by triturating a colony in Müller Hinton broth so as to obtain turbidity comparable to $0.5 \mathrm{Mac}$ Farland. $100 \mu \mathrm{l}$ of the suspension obtained is spread on a nutrient agar in order to appreciate its microbial load.
The $0.5 \mathrm{Mac}$ Farland standard was prepared with a mixture of $0.05 \mathrm{ml}$ of a $1 \%$ barium chloride solution and $9.95 \mathrm{ml}$ of a $1 \%$ sulfuric acid solution. The mixture is homogenized and stored in the dark at room temperature. ${ }^{20}$

Sterile microplates are placed under a hood with laminar flow. The wells of the first column are left empty, and $100 \mu l$ of Müller Hinton broth are dispensed into the other wells. Then, $200 \mu$ l of the extracts of concentration $100 \mathrm{mg} / \mathrm{ml}$ is introduced into the empty well of the first column and successive geometrical dilutions of reason 2 have been made successively using $100 \mu \mathrm{l}$ taken from the $200 \mu \mathrm{l}$ of undiluted extracts. $100 \mu \mathrm{l}$ of the microbial suspension is then added at each well.

Negative controls are carried out by putting $100 \mu \mathrm{l}$ of Muller Hinton broth only in one well and $100 \mu \mathrm{l}$ of extracts supplemented with $100 \mu \mathrm{l}$ of Mueller Hinton broth on the other hand. The MIC is determined by reading the plates. The MIC corresponds to the lowest concentration of the extract of the well which did not exhibit a culture visible to the naked eye. The determination of the MBC follows the colony count on the Petri dishes. The MBC corresponds to the concentration of the extract of the well which inhibits $99.99 \%$ of the starting inoculums.

\section{Qualitative phytochemical screening}

Qualitative phytochemical tests have identified alkaloids, flavonoids, tannins and saponosides according to standard procedures as described by Harbone. ${ }^{21}$ The alkaloids give turbidity or precipitate with the Dragendorf reagent. Flavonoids are colored red or orange in the presence of the Shibata reagent. The tannins are colored in black or blue-black by iron perchloride. After vigorous agitation of $15 \mathrm{~min}$, the persistence of foam of $1 \mathrm{~cm}$ for at least $5 \mathrm{~min}$ reveals the presence of saponosides.

\section{Quantitative phytochemical screening}

The total polyphenols assay used the Folin Ciocalteu reagent (FCR) as described by Singleton et al..$^{22}$ The principle is based on the oxidizing properties of the $\mathrm{OH}$ function of the phenols and on the reducing properties of the FCR. Reduction of the FCR reduces its colorimetric properties which are then quantified by spectrophotometry. The standard used is gallic acid. The Butanol/ $\mathrm{HCl}$ method was used to assay proanthocyanidins. It is a colorimetric reaction that takes place in two stages. In a first step, the polymers of flavan-3-ol are hydrolyzed in a butanol- $\mathrm{HCl}$ medium. The hydrolysis is complete and releases monomers of catechin and epicatechin type. The second step consists in oxidizing these monomers under the action of $\mathrm{Fe}^{\mathrm{III}}$ to give the cyanidin whose red coloring is a function of the concentration of proanthocyanidines..$^{23}$ The standard used is Catechin. The method used for the anti-radical tests is the phosphomolybdates reduction. The principle is based on the reduction of $\mathrm{Mo}^{\mathrm{VI}}$ molybdate to $\mathrm{Mo}^{\mathrm{V}}$ molybdate by the antioxidant compounds with the formation of a $\mathrm{Mo}^{\mathrm{V}}$ phosphomolybdate green complex which has a maximum absorption at $695 \mathrm{~nm} \cdot{ }^{24}$

\section{Statistical analysis}

A pre-test was carried out before the first manipulation. The tests were repeated twice. In each case, averages and errors were calculated for the concentrations measured in the two sets of experiments. These averages were statistically compared using one-factor ANOVA at $\mathrm{P}<0.05$. 


\section{Results and discussion}

In other to study the anti-Salmonella activities of extracts from Sarcocephalus latifolius, Lannea barteri, Uvaria chamae, Parkia biglobosa and Khaya senegalensis a microdilution technique was performed. ${ }^{18,19}$ Table 1 shows the MIC and the MBC of plants extracts on Salmonella strains. The anti-Salmonella investigation revealed MIC from 6.25 to $12.5 \mathrm{mg} / \mathrm{ml}$ with Sarcocephalus latifolius, $12.5 \mathrm{mg} /$ $\mathrm{ml}$ with Lannea barteri and $25 \mathrm{mg} / \mathrm{ml}$ with Uvaria chamae. The antiSalmonella activities obtained depend on plants extracts studied. But in general, all the different strains of Salmonella tested had the same behavior with the same extract. The hydroethanolic extracts of the root bark of Sarcocephalus latifolius had a bactericidal effect on strains at MIC of $6.25 \mathrm{mg} / \mathrm{ml}$ on Salmonella typhi, Salmonella typhimirium, Salmonella paratyphi, and $12.5 \mathrm{mg} / \mathrm{ml}$ on Salmonella enterica. This was consistent with the works of Deeni et al. ${ }^{6}$ and Aguora et al. ${ }^{5}$ on the antibacterial properties of the roots of Sarcocephalus latifolius. They found respectively MIC of $5 \mathrm{mg} / \mathrm{ml}$ with the hydromethanolic extracts and $10 \mathrm{mg} / \mathrm{ml}$ with aqueous extracts on Salmonella strains.

Table I MIC and MBC of Plants Extracts

\begin{tabular}{|c|c|c|c|c|c|c|c|c|c|c|}
\hline & $\begin{array}{l}\mathrm{MIC} \\
\mathrm{mg} / \mathrm{ml}\end{array}$ & $\begin{array}{l}\mathrm{MBC} \\
\mathrm{mg} / \mathrm{ml}\end{array}$ & $\begin{array}{l}\mathrm{MIC} \\
\mathrm{mg} / \mathrm{ml}\end{array}$ & $\begin{array}{l}\mathrm{MBC} \\
\mathrm{mg} / \mathrm{ml}\end{array}$ & $\begin{array}{l}\mathrm{MIC} \\
\mathrm{mg} / \mathrm{ml}\end{array}$ & $\begin{array}{l}\mathrm{MBC} \\
\mathrm{mg} / \mathrm{ml}\end{array}$ & $\begin{array}{l}\mathrm{MIC} \\
\mathrm{mg} / \mathrm{ml}\end{array}$ & $\begin{array}{l}\mathrm{MBC} \\
\mathrm{mg} / \mathrm{ml}\end{array}$ & $\begin{array}{l}\mathrm{MIC} \\
\mathrm{mg} / \mathrm{ml}\end{array}$ & $\begin{array}{l}\mathrm{MBC} \\
\mathrm{mg} / \mathrm{ml}\end{array}$ \\
\hline S.Typhi & 6.25 & 12.5 & 12.5 & 25 & 25 & 50 & 50 & 50 & 50 & $>50$ \\
\hline $\begin{array}{l}\text { S. paratyphi } \\
\text { ATCC 9I50 }\end{array}$ & 6.25 & 12.5 & 12.5 & 25 & 25 & 50 & 50 & 50 & 50 & $>50$ \\
\hline $\begin{array}{l}\text { S. typhimirium } \\
\text { ATCC I4028 }\end{array}$ & 6.25 & 12.5 & 12.5 & 25 & 25 & 50 & 50 & $>50$ & ND & ND \\
\hline
\end{tabular}

\section{ND, not determined}

Hydroethanolic extracts of the trunk bark of Lannea barteri had a bactericidal effect on the tested strains at a MIC of $12.5 \mathrm{mg} / \mathrm{ml}$. Njinga et al. ${ }^{8}$ also reported the anti-Salmonella activity of the plant, but he tested the chloroform and ethyl acetate fractions of the leaves on Salmonella typhi ATCC 9184 and find respectively MIC of 2.5 and $5 \mathrm{mg} / \mathrm{ml}$. Antibacterial properties of extracts from the trunk bark of the same plant have been reported by several authors, but they did not test Salmonella strains. Donkor et al..$^{25}$ studied the bactericidal and bacteriostatic activity of the aqueous and ethanol extracts of the trunk bark of Lannea barteri on another three Enterobacteriaceae; they found MIC from $6.25 \mathrm{mg} / \mathrm{ml}$ to $12.5 \mathrm{mg} / \mathrm{ml}$ with the aqueous and the ethanolic extracts.

Uvaria chamae's MIC and MBC did not change from one strain to another $(25 \mathrm{mg} / \mathrm{ml}$ and $50 \mathrm{mg} / \mathrm{ml}$ respectively). According to the value of the ratio $\mathrm{MBC} / \mathrm{MIC}$, the extract has a bactericidal effect on the strains tested..$^{26}$ Ogbulie et al. ${ }^{11}$ also found bactericidal activity of ethanolic extracts from the roots of the same plant, but they used the disk diffusion technique on agar; and obtained an inhibition zone of 16 $\mathrm{mm}$ diameter with a concentration of $100 \mu \mathrm{g} / \mathrm{ml}$ on Salmonella typhi. Antibacterial properties of root extracts of the same plant have been reported by Kone et al. ${ }^{10}$ but they tested a species of enterobacteria (Shigella) which has many characteristics in common with Salmonella Table 2 Chemical components of plants extracts and obtained MIC of $3.125 \mathrm{mg} / \mathrm{ml}$ for the ethanol extract and $6.25 \mathrm{mg} /$ $\mathrm{ml}$ for the aqueous extract.

Results also showed a bactericidal effect of the hydroethanolic extracts of the trunk bark of Parkia biglobosa on the tested strains with a MIC of $50 \mathrm{mg} / \mathrm{ml}$. The bactericidal effect of the extracts of this plant has been previously proven by Millogo-Kone et al. ${ }^{14}$ with a MIC lower than that obtained in this study. They found a MIC of $2.5 \mathrm{mg} /$ $\mathrm{ml}$ with the hydroalcoholic extracts of trunk bark on Salmonella enterica CIP 105 140. Bukar et al. ${ }^{27}$ also obtained anti-Salmonella activities with extracts of the same plant; but this study focused on the leaves and pods. Hydroethanolic extracts of Khaya senegalensis trunk bark inhibited strains of Salmonella typhi, Salmonella enterica and Salmonella paratyphi at an initial concentration of $50 \mathrm{mg} / \mathrm{ml}$. The extract had no activity on Salmonella typhimirium at the initial concentration of $50 \mathrm{mg} / \mathrm{ml}$. There is no significant difference with the results obtained by Abdallah et al., ${ }^{17}$ who found a MIC of $50 \mathrm{mg} / \mathrm{ml}$ for the aqueous extract and $25 \mathrm{mg} / \mathrm{ml}$ for the ethanolic extract of the trunk bark of Khaya Senegalensis on a strain of the genus Salmonella. These values are lower than those obtained by Ugoh et al. ${ }^{28}$ who also conducted antimicrobial tests of aqueous and ethanolic extracts of the trunk bark of Khaya senegalensis and found a MIC of $200 \mathrm{mg} / \mathrm{ml}$ for both extracts on a strain of Salmonella typhi.

\begin{tabular}{llllll}
\cline { 2 - 5 } & Alcaloïdes & Flavonoïdes & Tanins & Saponosides \\
\hline K. senegalensis & ++ & ++ & +++ & + \\
P. biglobosa & ++ & ++ & +++ & ++ \\
L. barteri & ++ & ++ & +++ & - \\
S. latifolius & +++ & + & + & ++ \\
U. chamae & ++ & + & ++ & ++ \\
\hline
\end{tabular}

-, absence; +, Trace; ++, scanty; +++, Abundant 
The differences observed with the other authors could be explained by several factors, including the nature of the solvents of extractions and the antimicrobial tests used. In other to access to chemical components of this extracts, qualitative and quantitative evaluation were performed using standard phytochemical and phosphomolybdates reduction procedures. ${ }^{21-24}$ Regarding the qualitative evaluation, results showed that all extracts studied contained alkaloids, flavonoids and tannins (Table 2). Saponosides has been revealed in extracts of the trunk bark of Khaya senegalensis, Parkia biglobosa, roots of Sarcocephalus latifolius and Uvaria chamae; but they were tested negative in the extracts of the trunk bark of Lannea barteri.

Table 3 Chemical contents of plants extracts
These results confirmed the report of several authors with extracts of Khaya senegalensis, ${ }^{29}$ Parkia biglobosa ${ }^{30}$ Lannea barteri, ${ }^{8}$ Sarcocephalus latifolius ${ }^{5}$ and Uvaria chamae. ${ }^{10}$ It also show that the tannins are more concentrated in the trunk bark extracts than the root extracts. The anti-Salmonella properties obtained with these extracts would probably be related to the isolated or conjugated action of one or some of these chemical compounds highlighted.

According to the quantitative evaluation, Table 3 shows the contents of total polyphenols, proanthocyanidins and antioxidants.

\begin{tabular}{llll}
\hline & Total Polyphenols (mg EGA/g) & Proanthocyanidines $(\mathbf{m g ~ E C / g )}$ & Antioxydants (mg EAA/g) \\
\hline K. senegalensis & $18.53 \pm 0.03$ & $62.85 \pm 0.67$ & $9.12 \pm 0.17$ \\
P. biglobosa & $33.24 \pm 0.14$ & $57.14 \pm 0.08$ & $9.30 \pm 0.15$ \\
L. barteri & $18.03 \pm 0.14$ & $67.14 \pm 0.23$ & $8.28 \pm 0.23$ \\
S. latifolius & $05.29 \pm 0.21$ & $35.71 \pm 0.26$ & $5.53 \pm 0.06$ \\
U. chamae & $11.66 \pm 0.08$ & $60.00 \pm 1.19$ & $5.76 \pm 0.18$ \\
\hline
\end{tabular}

EGA, equivalent gallic acid; EC, equivalent catechin; EAA, equivalent ascorbic acid

The concentrations of total polyphenols are $18.53 \pm 0.03 \mathrm{mg} \mathrm{EGA} / \mathrm{g}$ for Khaya senegalensis, $33.24 \pm 0.14 \mathrm{mg}$ EAG/g for Parkia biglobosa and $18.03 \pm 0.14 \mathrm{mg}$ EAG/g for Lannea barteri. All extracts possess antioxidants. This shows that they displayed anti-radical potential. The stem bark of Khaya senegalensis, Parkia biglobosa and Lannea barteri displayed the high anti-radical properties with respectively $9.12 \pm 0.17 \mathrm{mg} \mathrm{EAA} / \mathrm{g}, 9.30 \pm 0.15 \mathrm{mg}$ EAA/g and $8.28 \pm 0.23 \mathrm{mg} \mathrm{EAA} / \mathrm{g}$ values of antioxidants. This confirms the anti-radical properties reported by many authors with the extracts of Khaya senegalensis, ${ }^{16}$ Parkia biglobosa ${ }^{13}$ Sarcocephalus Latifolius ${ }^{5}$ and Uvaria chamae. ${ }^{10}$ These results also showed that total polyphenols and antioxidants concentrations are higher in trunk bark extracts than in root extracts. By comparing these results with those of qualitative phytochemical analysis, a hypothesis could be deduced that there would probably be a relationship between the levels of tannins, total polyphenols and antioxidants.

\section{Conclusion}

This study showed that the plants extracts tested contain alkaloids, flavonoids and tannins. The reduction of the phosphomolybdates by these various extracts proved that they are endowed with the antiradical properties. The anti-Salmonella tests allowed classifying the extracts into three categories according to their activities. Extracts of the trunk bark of Khaya senegalensis and Parkia biglobossa had low activity on some Salmonella strains at MIC $50 \mathrm{mg} / \mathrm{ml}$. Uvaria chamae root extract gave an average activity on all strains at MIC $25 \mathrm{mg} / \mathrm{ml}$. The strongest activities are obtained with extracts of Sarcocephalus latifolius root bark and Lannea barteri trunk bark at MIC ranging from 6.25 to $12.5 \mathrm{mg} / \mathrm{ml}$. This study therefore supports the traditional use of these plants in Togo and different regions of the world, and may serve as a good source of new drugs against Salmonellosis and oxidative-related diseases.

\section{Acknowledgements}

The authors would like to thank medicinal plants sellers of "LoméAdawlouato" market, and traditional healers of "CERMETRATOGO".

\section{Conflict of interest}

The authors declare there is no conflict of interest.

\section{References}

1. Walsh. Antibiotics: actions, origins, resistance. Washington DC: ASM Press; 2003. 345 p.

2. WHO. Manual for the laboratory identification and antimicrobial susceptibility testing of bacterial pathogens of public health importance in the developing world. Switzerland. 2003.103-162 p.

3. Maghrani M, Zeggwagn N, Michel J, et al. Antihypertensive effect of Lepidium sativum in spontaeneously hypertension rats. $J$ Ethpharmacol. 2005;100(102):193-197.

4. Abbah J, Asmos S, Chindo B, et al. Pharmacological evidence favouring the use of Nauclea latifolia in malaria ethnopharmacy: Effects against nociception, inflammation, and pyrexia in rat and mice. J Ethnopharmacol. 2010;127(1):85-90.

5. Antia B, Okokon J. Phytochemical composition and antidiabetic activity of ethanol root extract of Nauclea latifolia. The journal of phytopharmacology. 2014;3(1):52-56.

6. Deeni Y, Hussain H. Screening for antimicrobial activity and for alkaloids of Nauclea latifolia. J Ethnopharmacol. 1991;31(1):91-96.

7. Garba K, Yaro A, Ya'u J. Anticonvulsivant effects of ethanol stem bark extract of Lannea barteri (Anacardiaceae) in mice and chicks. $J$ Ethnopharmacol. 2015;172:227-231. 
8. Njinga N, Sule M, Pateh U, et al. Phytochemical and antimicrobial activity of the leaves of Lannea kerstingii engl and $k$. krause (anacadiaceae). Nitte University Journal of Health Science. 2014;4(4):1-41.

9. Agassounon DT, de Souza C, Anani KT, et al. Evaluation des activités cytotoxique, antivirale, antibactérienne et antifongique de six plantes médicinales. Pharm Méd Trad Afr. 2001;11:93-105.

10. Kone M, Toure A, Ouatara K, et al. Phytochemical composition, antioxydant and antibacterial activities of root of Uvaria chamae P. Beauv. (Annoceae) used in treatment of Dysentery in north of Cote d'Ivoire. International Journal of Pharmacognosy and Phytochemical Research. 2015;7(6):1047-1053.

11. Ogbulie J, Ogueke C, Nwanebu F. Antibacterial proprerties of Uvaria chamae, Congronema latifolium, Garcinia kola, Venomia amygdalina and Aframomum melegueta. African Journal of Biothechnology. 2007;6(13):1549-1553

12. Ajaiyeoba E. Phytochemical and antibacterial properties of Parkia biblogosa and Parkia bicolor leaf extracts. African journal of biomedical research. 2002;5:125-129.

13. Komolafe K, Oyelade W. Phytochemical screening and in vitro antioxidant activity of Parkia biglobosa extract. Journal of Biology, Agriculture and Healthcare. 2015;5(9):91-9524.

14. Millogo-Kone H, Guissou I, Nacoulma O, et al. Antimicrobial effect of the stem bark extracts of Parkia biblogosa (Jacq.) Benth on Shigella. Afr J Tradit Complement Altern Med. 2007;4(4):392-396.

15. Diatta C, Gueye M, Akpo L. Les plantes médicinales utilisées contre les dermatoses dans la pharmacopée Baïmounk de Djibonker, région de Ziguinchor (Sénégal). J Appl Biosci. 2013;70:5599-5607.

16. Atawodi S. Assesment of the polyphenol profile and antioxidant properties of leaves, stem bark and root barks of Khaya senegalensis. Electronic Journal of Biology. 2009;5(4):80-84.

17. Abdallah M, Ahmed I, Yahaya S. Antibacterial activity and phytochemical screening of leaf and stem (bark) extract of khaya senegalensis against diarreal/stool isolates. CIBTech Journal of Microbiologie. 2016;5(1):17-24.

18. Satyajit D, Sarker S, Nahar L, et al. Microtitre plate-based antibacterial assay incorporating resazurin as an indicator of cell growth, and its application in the in vitro antibacterial screening of phytochemicals. Methods. 2007;42(4):321-324.

19. Aguora S, Unekwe P, Okechukwu E. In Vitro Studies of Antibacterial Activities of Nauclea latifolia Root Extracts Using Micro Dilution Indicator Technique. Journal of Dental and Medical Sciences. 2015;14:29-34.
20. McFarland J. The nephelometer: an instrument for media used for estimating the number of bacteria in suspensions used for calculating the opsonic index and for vaccines. J Am Med Assoc. 1907;14:11761178 .

21. Harbone J. Phytochemical methods. London: Chapman and Hall publication; 1999:7-8.

22. Singleton V, Orthofer R, Lamuela-Raventos R. Analysis of total phenols and other oxidation substrates and antioxydants by means of Folin-Ciocalteu reagent. Methods of Enzymology.1999;299:152-178.

23. Porter L, Hritsch L, Chan B. The conversion of procyanidins and prodelphinidins to cyanidin. Phytochemistry. 1986;25:223-230.

24. Prieto P, Pineda M, Aguilar M. Spectrophotometric quantification of antioxydant capacity through the formation of a phosphomolybdenum complex: specific application of vitamin E analytical. Biochemistry. 1999;269:337-341

25. Donkor A, Mosobil R, Suurbaar J. In vitro bacteriostatic and bactericidal activities of Sena alata, Ricinus communis and Lannea barteri extracts against wound and skin disease causing bacteria. $J$ Anal Pharm Res. 2016;3(1):00046.

26. Kone M, Soro D, Dro B, et al. Chemical Composition, antioxidant, antimicrobial and acetylcholinesterase inhibitory properties of Lannea barteri (Anacatdiaceae). Australian Journal of Basic and Applied Sciences. 2011;5(10):1516-1523.

27. Bukar A, Uba A, Oyeyi T. Phytochemical analysis and antimicrobial activity of Parkia biglobosa (Jacq.) Benth. extracts against some food-borne microorganismes. Advance in Environemental Biology. 2010;4(1):74-79.

28. Ugoh S, Agarry O, Garba S. Studies on the antibacterial activity of Khaya senegalensis [(Desr.) A. Juss] stem bark extract on Salmonella enterica subsp. enterica serovar Typhi [(ex Kauffman and Edwards) le Minor and Popoff]. Asian Pacific Journal of Tropical Biomedicine. 2014;4(1):279-283.

29. Kankia H, Zainab S. Phytochemical analysis and antimicrobial activity of methanolic and ethanolic leaves, barks and roots crude extracts of Khaya senegalensis. International Journal of Scientific and Research Publication. 2015;5(1).

30. Abioye O, Akinpelu A, Aiyegoro A, et al. Preliminary phytochemical screening and antibacterial properties of crude stem bark extracts and fractions of Parkia biglobosa (Jacq.). Molecules. 2013;18(7):84858499. 